Agr. Biol. Chem., 39 (4), 785 790, 1975

\title{
Ribonucleic Acids with Messenger Activities in the Cotyledons of Soybean Seeds
}

\author{
Tomohiko Mori and Zen-ichi YoKoYAMA* \\ Research Institute for Food Science, Kyoto University, Kyoto
}

Received August 16, 1974

\begin{abstract}
Ribonucleic acids from the cotyledons of soybean seeds (H-RNA) stimulated the amino acid incorporation in a cell-free system prepared from soybean seedlings at a concentration of $5 \mathrm{~mm}$ magnesium acetate. In a reticulocyte cell-free system H-RNA stimulated the amino acid incorporation at a concentration of $10 \mathrm{~mm} \mathrm{Mg}^{2+}$, but not at $4.3 \mathrm{mM} \mathrm{Mg}^{2+}$ Aurintricarboxylate, an inhibitor for the initiation of protein synthesis, inhibited the H-RNA and TMV-RNA-stimulated amino acid incorporation by about $90 \%$ and $70 \%$ at a concentration of $50 \mu \mathrm{M}$ in $E$. coli and soybean seedling systems, respectively. When the H-RNA preparation was passed through a Millipore filter, about $1 \%$ of the charged RNA was retained on the filter. Chromatography on plain cellulose of H-RNA resulted in slight enrichment of an RNA fraction with the characteristics of mRNA.
\end{abstract}

We have been studying the ribonucleic acids that have messenger activities in the soluble fraction prepared from the cotyledons of soybean seeds. It has been suggested that the messenger activity was due to that some mRNA species existed in the RNA preparation, while major RNA components might be rRNAs and their derivatives. In dry wheat embryos, a subcellular fraction which stimulated in vitro amino acid incorporation ${ }^{1}$ and a ribosomal fraction having endogenous template activity ${ }^{2}$, have been isolated. The messenger fractions were suggested to be a ribonucleoprotein ${ }^{1)}$ or in complex form within the ribosomal fraction. ${ }^{2}$ We have also reported that ribonucleic acids with template activities were in the particulate forms, $37 \mathrm{~S}$ and $59 \mathrm{~S}$ in the post-ribosomal supernatant of soybean seeds. ${ }^{3}$ ) On the other hand, in the cotyledons of cottonseeds, it has been demonstrated that the mRNA for two enzymes (a

* Present address: Laboratory of Biochemistry, Kobe Yamate Women's College, Kobe.

Abbreviations used: H-RNA, high molecular weight RNA of soybean seeds prepared as shown in the text; ATA, aurintricarboxylate; DTT, dithiothreitol; EDTA, ethylenediaminetetraacetic acid; PVS, polyvinyl sulfate (potassium salt); SDS, sodium dodecyl sulfate; TCA, trichloroacetic acid; TMV, tobacco mosaic virus. carboxypeptidase and isocitratase) was transcribed in embryogenesis and translated in the germination process. ${ }^{4)}$ These results may indicate the existence of conserved mRNA not only in the embryos but also in the cotyledons of the seeds.

In this paper we attempt to examine some characteristics of the messenger activity of $\mathrm{H}$ RNA preparation to support the presence of mRNA species in the RNA preparation.

\section{MATERIALS AND METHODS}

Materials. Leucine-U-14 $\mathrm{C} \quad(282 \mathrm{mCl} / \mathrm{mmole})$ was purchased from Daiichi Pure Chem. Co. Sigmacell type 38 obtained from Sigma Chemical Co. was used as cellulose. Millipore filter (HA $0.45 \mu \mathrm{m}$ ) was purchased from Millipore Filter Corp. The ammonium salt of aurintricarboxylic acid (ATA) was purchased from Nakarai Chemicals Ltd.

Preparation of $H-R N A$. Soybean seeds were soaked overnight in water at $4^{\circ} \mathrm{C}$. Cotyledons detached from germs were homogenized in a mortar with $50 \mathrm{~mm}$ Tris- $\mathrm{HCl}$ buffer ( $\mathrm{pH} 7.8$ ) containing $0.25 \mathrm{M}$ sucrose, $1 \mathrm{~mm}$ magnesium acetate and $5 \mu \mathrm{g} / \mathrm{ml}$ of PVS. The homogenate was squeezed through gauze and centrifuged at $10,000 \times g$ for $30 \mathrm{~min}$. The supernatant was centrifuged at $100,000 \times g$ for $1 \mathrm{hr}$. RNA was prepared from the supernatant (S-100 RNA) as described previously5) except that SDS was added in a final concentration of $0.5 \%$ before phenol extraction. H-RNA 
was prepared from S-100 RNA by Sephadex G-200 column chromatography as described previously ${ }^{6}$ ) except that the elution was done in the presence of PVS $(5 \mu \mathrm{g} / \mathrm{ml})$.

Preparation of TMV-RNA. The ordinary strain of TMV (strain OM) was used. Virus-infected leaves were made available by the courtesy of Dr. F. Sakai, Institute for Plant Virus Research, Chiba, and the virus was prepared by differential centrifugation according to the method of Boedtker and Simmons ${ }^{7}$ ) with slight modification as follows. The juice from the frozen leaves was clarified by centrifugation at $10,000 \times g$ for $15 \mathrm{~min}$, and the supernatant fluid was centrifuged at $100,000 \times g$ for $1 \mathrm{hr}$. The pellet was dispersed in $0.1 \mathrm{M}$ potassium phosphate $(\mathrm{pH} 7)$ by allowing it to soak overnight. It was subjected to the same cycle of low speed then high speed centrifugations. The pellet was dispersed in water by allowing it to soak overnight, followed by the addition of an equal volume of $20 \mathrm{~mm}$ EDTA ( $\mathrm{pH} 7.5$ ). The suspension was centrifuged at $10,000 \times g$ for $15 \mathrm{~min}$, and the supernatant fluid was centrifuged at $100,000 \times g$ for $1 \mathrm{hr}$. The pellet (TMV) thus obtained was dispersed in water. TMV-RNA was prepared by bentonite-phenol extraction from the TMV.81

Preparation of ribosomal and supernatant fractions from soybean seedlings. Ribosomal fraction was prepared from hypocotyls of 2-day-old soybean seedlings which were germinated in vermiculite at $25^{\circ} \mathrm{C}$ in the dark. Hypocotyls were homogenized in a mortar with a solution containing $1 \mathrm{~mm}$ magnesium acetate, $2 \mathrm{~mm}$ $\mathrm{CaCl}_{2}$ and $50 \mathrm{mM} \mathrm{KCl}$ and the homogenate was centrifuged at $24,000 \times g$ then $100,000 \times g$, as described by Marcus et al. ${ }^{9)}$ The ribosomal pellet (crude ribosomes) was washed once by repelleting from the suspending medium containing $50 \mathrm{~mm}$ Tris- $\mathrm{HCl}$ buffer ( $\mathrm{pH} \mathrm{7.6)}$, $0.5 \mathrm{M} \mathrm{KCl}, 5 \mathrm{~mm}$ magnesium acetate, $1 \mathrm{~mm}$ 2-mercaptoethanol and $0.25 \mathrm{~m}$ sucrose. Ribosomal pellet (washed ribosomes) was dissolved in a suspending medium containing $40 \%$ glycerol. Supernatant was prepared from cotyledons of 2- or 3-day-old soybean seedlings by centrifugation at $100,000 \times g$ and treated with Sephadex G-25 as described previously. ${ }^{101}$

Preparation of ribosomal and $\mathrm{pH} 5$ fractions from reticulocytes. Male white rabbits were used in the experiments. Induction of reticulocytosis by phenylhydrazine injection and the preparation of lysate, ribosomes and $100,000 \times g$ supernatant fraction was performed according to the procedures reported by Schreier and Staehelin. ${ }^{11}$ The $\mathrm{pH} 5$ fraction was prepared from the post-ribosomal supernatant by the method described below.

Preparation of rat liver pH 5 fraction. $\mathrm{A} \mathrm{pH} 5$ fraction was prepared according to the method de- scribed by Hoagland et al. ${ }^{12)}$ with slight modifications. ${ }^{131}$ Rat livers were homogenized in $10 \mathrm{~mm}$ Tris- $\mathrm{HCl}$ buffer (pH 7.5) containing $0.3 \mathrm{~m}$ sucrose, $5 \mathrm{~mm}$ magnesium acetate and $1 \mathrm{mM} \mathrm{DTT}$, and the post-mitochondrial supernatant was prepared by centrifugation at $17,500 \times g$ for $15 \mathrm{~min}$. The supernatant was then centrifuged at $100,000 \times g$ for $3 \mathrm{hr}$. Approximately two-thirds of the supernatant fluid was then diluted with 2 volumes of cold distilled water containing $1 \mathrm{~mm}$ DTT and the $\mathrm{pH}$ was adjusted to 5.1 to 5.2 by dropwise addition of $1 \mathrm{M}$ acetic acid with constant stirring. The suspension was centrifuged at $10,000 \times g$ for $10 \mathrm{~min}$ and the precipitate was dissolved in $20 \mathrm{~mm}$ Tris- $\mathrm{HCl}$ buffer $(\mathrm{pH} 7.5)$ containing $0.1 \mathrm{M} \mathrm{NH}_{4} \mathrm{Cl}, 5 \mathrm{~mm}$ magnesium acetate and $1 \mathrm{~mm}$ DTT. The $\mathrm{pH}$ was adjusted to 7.5 by addition of small amounts of $1 \mathrm{~N} \mathrm{KOH}$.

Preparation of E. coli S-30 fraction. E. coli strain $\mathrm{K}-12$ cells harvested at 0.6 of absorbance at $520 \mathrm{~nm}$ with $1 \mathrm{~cm}$ light path were ground with alumina. The S-30 fraction $(30,000 \times g$ supernatant $)$ was prepared by differential centrifugation and preincubated at $37^{\circ} \mathrm{C}$ for $80 \mathrm{~min}$ as described by Nirenberg. ${ }^{14}$

All operations were carried out at $0 \sim 5^{\circ} \mathrm{C}$. The subcellular preparations obtained above were stored in liquid nitrogen and RNA preparations were stored at $-20^{\circ} \mathrm{C}$.

\section{Cell-free amino acid incorporation systems}

Reticulocyte system. The reaction mixture of $0.2 \mathrm{ml}$ contained $0.146 \mathrm{mg}$ protein of ribosomes, 5.834 O.D.260 units of H-RNA preparation, $0.639 \mathrm{mg}$ protein of $\mathrm{pH} 5$ fraction and the following ingredients per $\mathrm{ml}: 30 \mu$ moles Tris- $\mathrm{HCl}$ ( $\mathrm{pH} 7.6)$, magnesium acetate as indicated, $70 \mu$ moles $\mathrm{KCl}, 1 \mu$ mole DTT, 30 nmoles each of 19 amino acids except for leucine, $1 \mu$ mole ATP, $0.4 \mu$ mole GTP, $20 \mu$ moles creatine phosphate, $50 \mu \mathrm{g}$ creatine kinase and $2.5 \mu \mathrm{Ci}$ leucine- $\mathrm{U}-{ }^{14} \mathrm{C}$. Incubation was carried out at $37^{\circ} \mathrm{C}$ for $30 \mathrm{~min}$.

Soybean seedling system. The reaction mixture of $0.1 \mathrm{ml}$ contained ribosomes and supernatant from soybean seedlings (or rat liver pH 5 fraction), H-RNA or TMV-RNA preparations and the following ingredients per ml: $50 \mu$ moles Tris- $\mathrm{HCl}(\mathrm{pH} 7.8), 5 \mu$ moles magnesium acetate, $40 \mu$ moles $\mathrm{KCl}, 1 \mu$ mole DTT, 20 nmoles each of 19 amino acids, $1 \mu$ mole ATP, $0.25 \mu$ mole GTP, $10 \mu$ moles creatine phosphate, $50 \mu \mathrm{g}$ creatine kinase and $2 \mu \mathrm{Ci}$ leucine-U $-{ }^{14} \mathrm{C}$. Incubation was carried out at $37^{\circ} \mathrm{C}$ for $20 \mathrm{~min}$.

E. coli system. The amino acid incorporation system used was basically the same as that of Nirenberg. ${ }^{14)}$ The reaction mixture of $0.1 \mathrm{ml}$ contained $0.147 \mathrm{mg}$ protein of S-30, H-RNA or TMV-RNA preparations and the following ingredients per $\mathrm{ml}$ : $50 \mu$ moles Tris- $\mathrm{HCl}$ ( $\mathrm{pH}$ 7.8), $10 \mu$ moles magnesium 
acetate, $75 \mu$ moles $\mathrm{KCl}, 1 \mu$ mole DTT, 20 nmoles each of 19 amino acids, $3 \mu$ moles ATP, $0.25 \mu$ mole GTP, $10 \mu$ moles creatine phosphate, $50 \mu \mathrm{g}$ creatine kinase and $2 \mu \mathrm{Ci}$ leucine-U ${ }^{14} \mathrm{C}$. Incubation was carried out at $37^{\circ} \mathrm{C}$ for $15 \mathrm{~min}$.

Measurement of radioactivity. Reaction was stopped by applying an aliquot of the incubation mixture to a filter paper disk and the disk was plunged into a beaker of ice-cold $10 \%$ TCA. ${ }^{15}$ l The disk was washed with cold $5 \% \mathrm{TCA}$, heated at $90^{\circ} \mathrm{C}$ for $15 \mathrm{~min}$ in $5 \%$ TCA, washed again with cold $5 \%$ TCA, washed with ethanol followed by acetone and dried in air. The disk was placed into a counting vial containing $10 \mathrm{ml}$ of toluene-PPO-POPOP scintillation liquid and counted in a Packard Tricarb Scintillation Spectrometer at $48.8 \%$ efficiency.

Adsorption on Millipore filter. The RNA preparations were diluted with $10 \mathrm{mM}$ Tris- $\mathrm{HCl}$ buffer $(\mathrm{pH}$ 7.6) containing $0.5 \mathrm{M} \mathrm{KCl}$ and $1 \mathrm{~mm}$ magnesium acetate (around $0.25 \mathrm{mg} / \mathrm{ml}$ ), and passed through a Millipore filter presoaked in the same solution at a rate of approximately $1 \mathrm{ml} / \mathrm{min}$. The filter was kept in $1 \mathrm{ml}$ of an ice-cold solution of $0.5 \% \mathrm{SDS}$ in $0.1 \mathrm{M}$ Tris-HCl buffer ( $\mathrm{pH} \mathrm{9.0)}$ for $30 \mathrm{~min}$, with occasional shaking. The adsorbed material was thus eluted with this solution. A potassium dodecyl sulfate crystals formed were removed by centrifugation and absorbance at $260 \mathrm{~nm}$ was measured.

Cellulose chromatography. RNA preparation was applied to a $5 \mathrm{ml}$ cellulose column which had been equilibrated with $10 \mathrm{~mm}$ Tris- $\mathrm{HCl}$ buffer (pH 7.6) containing $0.5 \mathrm{M} \mathrm{KCl}$ and $0.2 \mathrm{mM} \mathrm{MgCl}_{2}$. The column was washed with application buffer until the absorbance at $260 \mathrm{~nm}$ had dropped below 0.05 . The adsorbed RNA was eluted with neutralized water. The non- adsorbed RNA was precipitated with ethanol, dissolved in water and dialyzed against water. The adsorbed material was concentrated by ultrafiltration using collodion bag and used for the in vitro amino acid incorporation system. The chromatography was performed at $20^{\circ} \mathrm{C}$.

\section{RESULTS AND DISCUSSION}

\section{Effects of $H-R N A$ on the amino acid incorpora-} tion in the soybean and reticulocyte systems

When rabbit reticulocyte cell-free system was used as an in vitro amino acid incorporation system, the increase of the incorporation by the addition of $\mathrm{H}-\mathrm{RNA}$ was observed at $10 \mathrm{~mm}$ $\mathrm{Mg}^{2+}$ (Table I). The stimulative effect of $\mathbf{H}$

Table I. Effects of H-RNA on the Amino Acid INCOPRORATION IN RABBIT RETICULOCYTE

SYSTEM

\begin{tabular}{clc}
\hline $\begin{array}{c}\text { Concentration } \\
\text { of } \mathrm{Mg}^{2+}\end{array}$ & H-RNA & $\begin{array}{c}\text { Leucine-14C } \\
\text { incorporated } \\
\text { (cpm per ml) }\end{array}$ \\
\hline $4.3 \mathrm{mM}$ & minus & 102,860 \\
& plus & 97,097 \\
$10.0 \mathrm{mM}$ & minus & 41,989 \\
& plus & 67,383 \\
\hline
\end{tabular}

RNA was not observed at lower $\mathrm{Mg}^{2+}$ concentration $(4.3 \mathrm{~mm})$ where specific chain initiation will occur. On the other hand, H-RNA stimulated the amino acid incorporation at $5 \mathrm{mM} \mathrm{Mg}^{2+}$ in the cell-free system prepared

Table II. EfFects of H-RNA And TMV-RNA on the Amino Acid Incorporation in Soybean Seedling System

The amounts of components used in experiments were $0.148 \mathrm{mg}$ of crude ribosomes or $0.131 \mathrm{mg}$ of washed ribosomes and $0.4 \mathrm{mg}$ of supernatant fractions from soybean seedlings or $0.362 \mathrm{mg}$ of rat liver pH 5 fraction, as protein amounts and $2.288 \mathrm{OD}_{260}$ units of $\mathrm{H}-\mathrm{RNA}$ or $1.282 \mathrm{OD}_{260}$ units of TMV-RNA.

\begin{tabular}{llccc}
\hline \multirow{2}{*}{ Ribosomes } & RNAs & \multicolumn{2}{c}{ Leucine-14C incorporated (cpm per ml) } \\
& & & $\begin{array}{c}\text { Supernatant fractions } \\
\text { 3-Coty }\end{array}$ & Rat liver pH 5 fraction \\
\hline Crude ribosomes & None & 1240 & 544 & 8002 \\
& H-RNA & 1594 & 1008 & 7846 \\
& TMV-RNA & 1866 & 1200 & 8186 \\
Washed ribosomes & None & 378 & 208 & 2502 \\
& H-RNA & 540 & 402 & 2432 \\
& TMV-RNA & 600 & 398 & 2592 \\
\hline
\end{tabular}

a) Cotyledons of 2-day-old soybean seedlings.

b) Cotyledons of 3-day-old soybean seedlings. 
from soybean seedlings (Table II). TMVRNA which was used as a natural mRNA showed similar stimulative effect in a crude ribosome system. H-RNA and TMV-RNA stimulated the amino acid incorporation in $0.5 \mathrm{M} \mathrm{KCl}$-washed ribosome system at $5 \mathrm{~mm}$ $\mathrm{Mg}^{2+}$ in the presence of the supernatant fraction. The pH 5 fraction from rat liver enhanced the amino acid incorporation level both in crude and washed ribosome systems but was not effective for the stimulation of the incorporation by the addition of exogenous mRNA. The initiation factors have recently been found in the soluble fraction in wheat embryos $^{16,17)}$ and in either the ribosomal or the soluble fractions in developing pea cotyledons. ${ }^{18)}$ In pea cotyledons, it was shown that the initiation factors associated with ribosomes could be extracted with $0.5 \mathrm{M} \mathrm{KCl}$ from the ribosomes. The results obtained with washed ribosomes from soybean seedlings (Table II) may be explained by the existence of the initiation factors in the supernatant of soybean seedlings. It is not clear at present why HRNA did not show the stimulative effect in the reticulocyte system at lower $\mathrm{Mg}^{2+}$ concentration.

Effect of ATA on exogenous RNA-stimulated amino acid incorporation in $E$. coli $S-30$ and soybean seedling systems

The effects of ATA which is known as an inhibitor for the initiation of protein synthesis on the amino acid incorporation stimulated by H-RNA and TMV-RNA were shown in Table III. The amino acid incorporation corresponding to the addition of H-RNA was inhibited by $84 \%$ and $70 \%$ at a concentration of $50 \mu \mathrm{M}$ ATA in $E$. coli and soybean seedling systems, respectively. ATA inhibited similarly the TMV-RNA-stimulated amino acid incorporation by $92 \%$ and $63 \%$ in $E$. coli and soybean seedling systems, respectively. In E. coli cell-free system, Grollman and Stewart ${ }^{19)}$ described that f2-RNA-stimulated peptide synthesis was inhibited completely by $50 \mu \mathrm{M}$ ATA, and $30 \mu \mathrm{M}$ ATA allows endogenous protein synthesis to continue at $50 \%$ of
Table III. EfFects of ATA on the Amino ACID INCORPORATION STIMULATED BY H-RNA AND TMV-RNA

In soybean seedling system $0.224 \mathrm{mg}$ protein of ribosomes and $0.609 \mathrm{mg}$ protein of supernatant fraction were used. The amounts of RNAs used were $0.532 \mathrm{OD}_{260}$ unit of H-RNA and $0.125 \mathrm{OD}_{260}$ unit of TMV-RNA. ATA was added in a concentration of $50 \mu \mathrm{M}$ to the reaction mixture containing ribosomes prior to the addition of RNA preparations.

\begin{tabular}{lcc}
\hline \multirow{2}{*}{ Additions } & \multicolumn{2}{c}{$\begin{array}{c}\text { Leucine-14C incorporated } \\
\text { (cpm per ml) }\end{array}$} \\
\cline { 2 - 3 } & $\begin{array}{c}\text { Soybean } \\
\text { seedling } \\
\text { system }\end{array}$ & $\begin{array}{c}\text { E. coli } \text { S-30 } \\
\text { system }\end{array}$ \\
\hline None & 636 & 888 \\
ATA & 562 & - \\
H-RNA & $1086(450)^{a)}$ & $7136(6248)$ \\
H-RNA+ATA & $696(134)$ & $1896(1008)$ \\
TMV-RNA & $936(300)$ & $19,944(19056)$ \\
TMV-RNA +ATA & $668(106)$ & $1444(556)$ \\
\hline
\end{tabular}

a) Net incorporations corresponding to the addition of RNAs were shown in parenthesis.

the control rate. They concluded that ATA prevented the attachment of phage RNAs to ribosomes, thereby inhibiting viral peptide synthesis. Analogous results have been shown in wheat embryo system, ${ }^{20)}$ in which the effects of ATA on TMV-RNA-dependent amino acid incorporation and on amino acid incorporation catalyzed by endogenous polyribosomes were investigated. At a concentration of $25 \mu \mathrm{M}$ ATA, the TMV-RNA dependent system was completely inhibited. In contrast, polyribosome-catalyzed incorporation was unaffected at the same concentration of ATA and slightly inhibited at a concentration of $50 \mu \mathrm{M}$ ATA. From the experimental results, they demonstrated that the initial phase of amino acid incorporation dependent on exogenous mRNA involved an initiation reaction between ribosome and mRNA. Considering from the results obtained here and by other investigators, it appears likely that H-RNA preparation contains mRNA.

\section{Binding of $H-R N A$ to Millipore filter}

The presence of polynucleotide sequences rich in adenylic acid in mRNA has been 
recognized as a characteristic of eukaryotic mRNAs with only the exception of mRNAs for histones. RNA containing adenine-rich sequences have been shown to be retained on nitrocellulose membrane-filters (Millipore filters) at high ionic strength. ${ }^{21}$ As shown in Table IV a small portion of H-RNA was re-

TABLE IV. BINDING OF H-RNA TO Millipore Filters

\begin{tabular}{ccc}
\hline $\begin{array}{c}\text { H-RNA used } \\
\text { (OD }\end{array}$ & $\begin{array}{c}\text { RNa units) } \\
\text { (OD recovered }\end{array}$ & $\%$ Yield \\
\hline 13.3 & 0.185 & 1.39 \\
26.6 & 0.244 & 0.92 \\
53.2 & 0.513 & 0.96 \\
\hline
\end{tabular}

tained on Millipore filters when the filtration was performed in the presence of $0.5 \mathrm{M} \mathrm{KCl}$. The adsorbed materials were about $1 \%$ of the total amount of charged RNAs by three experiments. As pointed out by Brawerman et al., ${ }^{22}$ however, the possibility of the contamination of rRNAs in the adsorbed RNA could not be excluded.

Chromatography of $H-R N A$ on cellulose

RNA containing adenine-rich sequences has been separated selectively by binding to oligo(dT) or poly(U) covalently linked to cellulose. Recently, Kitos et al. ${ }^{23)}$ have demonstrated that at high ionic strength untreated cellulose can adsorb poly(A) and poly(A)containing RNA molecules. Schutz et al. ${ }^{24)}$ also reported that poly(A) and poly(A)-rich RNA (mRNA for globin and ovalbumin) was selectively bound to the Sigma microgranular cellulose, but rRNA and tRNA was not bound. As can be seen in Fig. 1, 1.3\% of H-RNA was retained by plain cellulose under conditions of high ionic strength. The retained material was eluted with water as a sharp peak. The elution profile was similar to that obtained with the RNA from rabbit reticulocyte polyribosomes. The unfractionated RNA and the cellulose-fractionated RNAs were checked for their ability to stimulate the amino acid incorporation in E. coli $\mathrm{S}-30$ system. Although

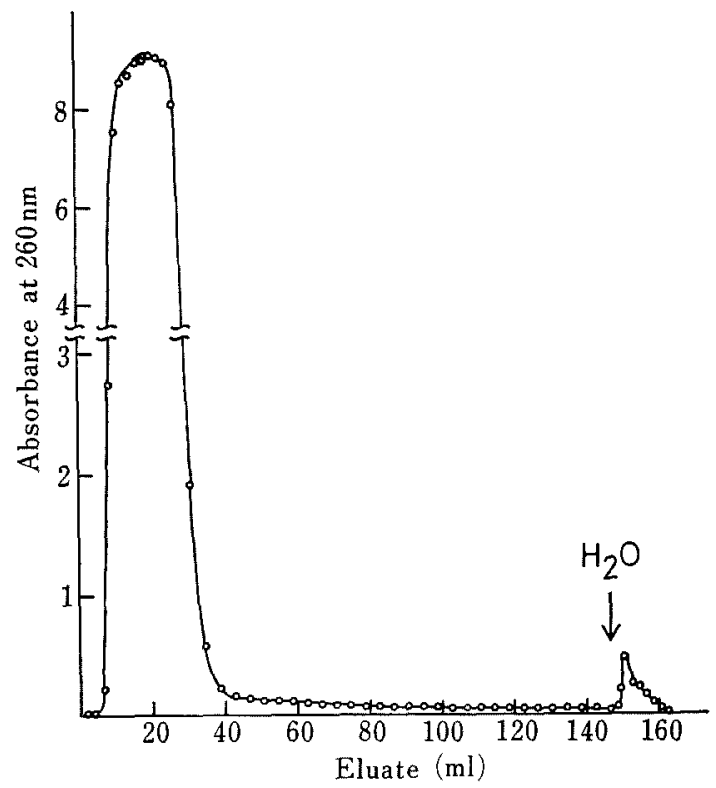

Fig. 1. Chromatography on Cellulose Column of H-RNA.

H-RNA preparation in $10 \mathrm{~mm}$ Tris- $\mathrm{HCl}$ (pH 7.6), $0.5 \mathrm{M} \mathrm{KCl}$ and $0.2 \mathrm{mM} \mathrm{MgCl}_{2}$ containing $228.8 \mathrm{OD}_{260}$ units in $20 \mathrm{ml}$ was applied and washed extensively with the same buffer solution. Elution with water was indicated by the arrow.

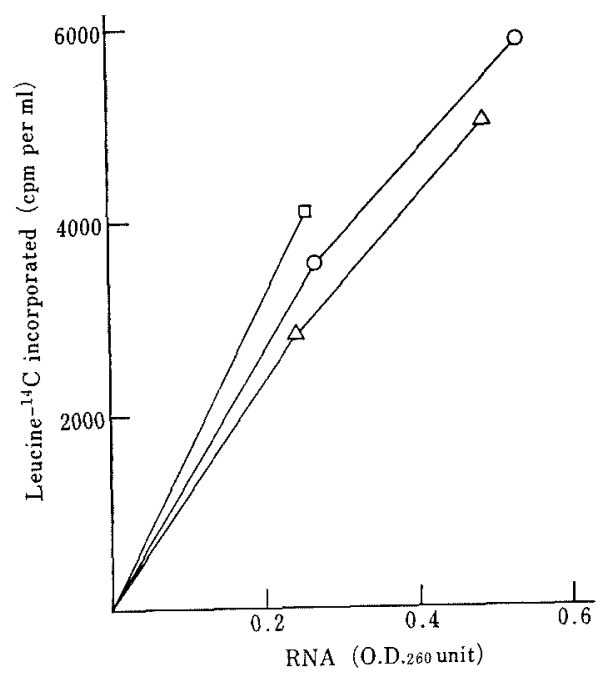

FIG. 2. Effects of Unfractionated and CelluloseFractionated RNAs on the Amino Acid Incorporation in $E$. coli $\mathrm{S}-30$ System.

Incorporation of leucine- ${ }^{14} \mathrm{C}$ into protein was measured in $0.1 \mathrm{ml}$ reaction mixture in the presence of the indicated amounts of RNA preparations as described in Materials AND Methods.

$\bigcirc-O$, unfractionated RNA (H-RNA); $\square-\square$, cellulose-adsorbed RNA; $\triangle-\triangle$, cellulose-through RNA. 
there was no large difference in the messenger activity of the RNA fractions obtained from the column chromatography, the material retained by the column was more effective than the unfractionated RNA in stimulating the amino acid incorporation (Fig. 2). Thus, the enrichment of RNA species containing poly(A) with messenger activity seems to be obtained by the cellulose chromatography. On the other hand, it has recently been reported that globin mRNA lacking the poly(A) sequence retained considerable messenger activity. ${ }^{25 \sim 27)}$ The result obtained here (Fig. 2) together with the findings of others suggests that the RNA fraction which could not be adsorbed on the cellulose column may still contain some mRNAs deficient in poly(A).

Acknowledgement. We wish to thank Dr. S. Matsushita for his encouragement and Dr. K. Sooda for his kind supply of bacteria.

\section{REFERENCES}

1) D. P. Weeks and A. Marcus, Biochim. Biophys. Acta, 232, 671 (1971).

2) G. A. Schultz, D. Chen and E. Katchalski, J. Mol. Biol., 66, 379 (1972).

3) T. Mori and S. Matsushita, Agr. Biol. Chem., 34, 1004 (1970).

4) J. N. Ihle and L. S. Dure, J. Biol. Chem., 247, 5048 (1972).

5) T. Mori, F. Ibuki, S. Matsushita and T. Hata, Agr. Biol. Chem., 33, 1229 (1969).

6) T. Mori, F. Ibuki, S. Matsushita and T. Hata, Arch. Biochem. Biophys., 124, 607 (1968).

7) H. Boedtker and N. S. Simmons, J. Am. Chem. Soc., 80, 2550 (1958).
8) H. Fraenkel-Contrat, B. Singer and A. Tsugita, Virology, 14, 54 (1961).

9) A. Marcus, B. Luginbill and J. Feeley, Proc. Nat. Acad. Sci. U.S.A., 59, 1243 (1968).

10) S. Matsushita, T. Mori and T. Hata, Mem. Res. Inst. Food Sci., Kyoto Univ., No. 29, 1 (1968).

11) M. H. Schreier and T. Staehelin, J. Mol. Biol, 73, 329 (1973).

12) M. B. Hoagland, M. L. Stephenson, J. F. Scott, L. I. Hecht and P. L. Zamecnik, J. Biol. Chem., 231, 241 (1958).

13) A. K. Falvey and T. Staehelin, J. Mol. Biol., 53, 1 (1970).

14) "Methods in Enzymology," Vol. VI, ed. by S. P. Colowick and N. O. Kaplan, Academic Press Inc., New York, N. Y., 1963, p. 17.

15) R. J. Mans and G. D. Novelli, Arch. Biochem. Biophys., 94, 48 (1961).

16) A. Marcus, J. Biol. Chem., 245, 962 (1970).

17) S. N. Seal, J. D. Bewley and A. Marcus, ibid., 247, 2592 (1972).

18) G. N. Wells and L. Beevers, Plant Sci. Lett., 1, 281 (1973).

19) A. P. Grollman and M. L. Stewart, Proc. Nat. Acad. Sci. U.S.A., 61, 719 (1968).

20) A. Marcus, J. D. Bewley and D. P. Weeks, Science, 167, 1735 (1970).

21) S. Y. Lee, J. Mendecki and G. Brawerman, Proc, Nat. Acad. Sci. U.S.A., 68, 1331 (1971).

22) G. Brawerman, J. Mendecki and S. Y. Lee, Biochemistry, 11, 637 (1972).

23) P. A. Kitos, G. Saxon and H. Amos, Biochem. Biophys. Res. Commun., 47, 1426 (1972).

24) G. Schutz, M. Beato and P. Feigelson, ibid., 49, 680 (1972).

25) R. Williamson, J. Crossley and S. Humphries, Biochemistry, 13, 703 (1974).

26) S. Humphries, M. Doel and R. Williamson, Biochem. Biophys. Res. Commun., 58, 927 (1974).

27) T.-C. Cheng, S. K. Polmar and H. H. Kazazian, Jr., J. Biol. Chem. 249, 1781 (1974). 